\title{
Nitrogen dynamics on Guam as revealed by the seagrass Enhalus acoroides
}

\author{
K. Pinkerton ${ }^{1}$, D. M. Baker ${ }^{2}$, M. R. Cuddy ${ }^{1}$, L. J. Raymundo ${ }^{3}$, K. A. Meyer ${ }^{1}$, K. Kim ${ }^{1, *}$ \\ ${ }^{1}$ Department of Environmental Science, American University, 4400 Massachusetts Ave NW, Washington, DC 20016, USA \\ ${ }^{2}$ School of Biological Sciences \& Department of Earth Science, University of Hong Kong, \\ Kadoorie Biological Sciences Building, Pokfulam Road, Hong Kong SAR \\ ${ }^{3}$ University of Guam Marine Laboratory, UOG Station, Mangilao, GU 96923, USA
}

\begin{abstract}
Seagrasses are critical to productive coastal ecosystems but are endangered and poorly studied, especially in the tropical Indo-Pacific. A key local threat is the increasing anthropogenic input of nitrogen $(\mathrm{N})$. We hypothesized that such $\mathrm{N}$ eutrophication is occurring on Guam, the largest and most populated of the Northern Mariana Islands. We examined the seagrass Enhalus acoroides over 5 years and applied stable isotope analysis to document $\mathrm{N}$ dynamics and impacts. Although $\delta^{15} \mathrm{~N}$ values indicated that sewage-derived $\mathrm{N}$ was the dominant source, the $\delta^{15} \mathrm{~N}$ values were unrelated to either seagrass cover or growth rate. Strong relationships between seagrass $\delta^{15} \mathrm{~N}$ values and both distance to the nearest source of $\mathrm{N}$ inputs and population density of adjacent municipalities suggest that $\mathrm{N}$ inputs are highly localized. Although there was no evidence of a negative impact of sewage-derived $\mathrm{N}$ inputs on seagrasses, this study provides a useful reference for evaluating mitigation efforts and for tracking the effect of increasing anthropogenic eutrophication on Guam.
\end{abstract}

KEY WORDS: Seagrasses · Tropical Indo-Pacific · Stable isotope analysis · Eutrophication

Resale or republication not permitted without written consent of the publisher

\section{INTRODUCTION}

Seagrasses are especially notable for the range and extent of ecosystem services they provide-e.g. $\mathrm{CO}_{2}$ sequestration, shoreline protection, nursery for commercially important fish species-and for being among the most endangered habitats on earth (Orth et al. 2006, Waycott et al. 2009, Barbier et al. 2011, Fourqurean et al. 2012). The threats to seagrasses are numerous and generally arise from a combination of climate change and being 'downstream' of human activities. In many places, nutrient pollution from human activities (i.e. anthropogenic eutrophication) is a key local driver of seagrass loss, but one that can be mitigated by reduction of inputs (Burkholder et al. 2007). The technology to remove nutrients from wastewater (i.e. tertiary sewage treatment) is very costly, however, and thus rarely implemented. Sea- grass degradation is especially problematic for tropical island communities, where the health and quality of the coastal environment (i.e. beaches, water, and marine life) forms the basis of important fishing and tourism-related economies (Gossling 2003, Graci \& Dodds 2010).

In spite of their importance, seagrasses have not been well studied, especially in the tropical IndoPacific, where they were historically widespread and abundant (Orth et al. 2006, Waycott et al. 2009, Unsworth \& Cullen 2010). In the coastal waters surrounding Guam, the largest of the Northern Mariana Islands, seagrasses currently make up $\sim 3 \%$ of the benthic habitat (Burdick 2005), a substantial decline from the $9 \%$ recorded 35 yr ago (Saeland 1978, cited in Eldrege 1983). The seagrasses of Guam comprise 3 species-Halodule uninervis, Halophila minor, and Enhalus acoroides-with E. acoroides being the 
most prominent (Lobban \& Tsuda 2003). Little else is known about the seagrass beds surrounding Guam, as available studies consist of species checklists with little or no ecological information (e.g. Tsuda et al. 1977, 2004).

This paucity of information is surprising given the ecological and economic importance of seagrass beds to Guam. For example, van Beukering et al. (2007) reported that tourism and fishing in Guam generate US\$127 million a year. Although only the coral reefs are highlighted in their assessment, it is almost certain that seagrass meadows and mangroves also contribute to the provisioning of ecosystem services related to tourism and fishing (Barbier et al. 2011). For instance, the annual 'manyahak run' (where juveniles of the rabbitfish Siganus spinus and $S$. argenteus spend a significant portion of their early life history in nearshore seagrass beds) is a wellknown and highly anticipated event among local fishers. In fact, Barbier et al. (2011) contend that seagrasses, along with corals and mangroves, make up an ecologically and physically connected coastal ecosystem that is more valuable than the individual habitats by themselves.

Nonetheless, the nearly 160000 residents of Guam (as of the 2010 US census; http://factfinder.census. gov/faces/tableservices/jsf/pages/productview.xhtml ?pid=DEC_10_DPGU_GUDP1\&prodType=table) are serviced by inadequate wastewater infrastructure comprising primary and secondary treatment plants (GWA 2006, Rainey \& Vanlerberghe 2013). Moreover, only $59 \%$ of the population is connected to sewer lines, with the remainder relying on septic tanks (GWA 2006). Consequently, nutrients rapidly enter the coastal waters, either through outfalls from sewage treatment plants, leaks and overflows from sewage pipes, or via groundwater, with the intensity of inputs being strongly modulated by rainfall (Marsh 1977, Matson 1993, Denton et al. 2005, Redding et al. 2013).

Nitrogen (N) stable isotope analysis of biological specimens is now a widely used approach for monitoring the status of nutrient pollution sources in a wide range of environments. Because seagrasses occur close to shore and tend to be nutrient limited, they are useful integrators and recorders of environmental nutrient conditions (Orth et al. 2006). In contrast, the rapid transformation of nutrients in the water column makes direct measurements of water quality less relevant for understanding biological processes than nutrient measurements in seagrasses (Burkholder et al. 2007). For these reasons, seagrasses have more and more often been used to assess anthropogenic eutrophication (see Christiaen et al. 2014 and references therein). Although Christiaen et al. (2014) found that $\mathrm{N}$ isotope values (i.e. $\left.\delta^{15} \mathrm{~N}\right)$ may not be useful for documenting the impact of urbanization on a regional scale, a number of studies have supported this relationship at the local level. Particularly compelling are studies showing a gradient in $\delta^{15} \mathrm{~N}$ values with distance from nutrient inputs. For instance, Connolly et al. (2013) showed that distance from a sewage outfall was a strong predictor of $\delta^{15} \mathrm{~N}$ values in seagrasses in the genera Posidonia and Zostera. In their study, Schubert et al. (2013) took local current patterns into consideration to demonstrate a similar relationship between $\delta^{15} \mathrm{~N}$ values for Zostera sampled up- and downstream of a sewage outfall along $5 \mathrm{~km}$ of the western Baltic coast. Although not the focus of this study, we also report on $\delta^{13} \mathrm{C}$, which we use to elucidate timing of terrestrial inputs of $\mathrm{C}$ coincident with the rainy season (Hemminga \& Mateo 1996).

In this study, we analyzed stable $\mathrm{N}$ isotopes in the seagrass $E$. acoroides to examine the impact and coastal dynamics of $\mathrm{N}$ in Guam. Our goal was to document how seagrass meadows are responding to changes in $\mathrm{N}$ dynamics and to establish a baseline for evaluating the impact of continued island development.

\section{MATERIALS AND METHODS}

\section{Study site}

Guam is the largest $\left(541 \mathrm{~km}^{2}\right)$, southernmost and most populated island in the Northern Marianas. Its hydrogeology is unique in that the island is composed of 2 distinct parts: the northern part consists of highly permeable limestone karst, while the southern part consists of less permeable volcanic terrain with a highly developed surface drainage network (Fig. 1). The island has a tropical climate with a relatively constant temperature throughout the year, a rainy season extending from July through November, and a dry season for the remainder of the year.

\section{Seagrass surveys and sampling}

The status of Enhalus acoroides, the dominant species of seagrass in Guam (Tsuda et al. 1977), was examined at 10 sites from mid-July to early August in 2009, 2011, and 2013 (Fig. 1, Table 1). These sites were selected based on the presence of seagrass 


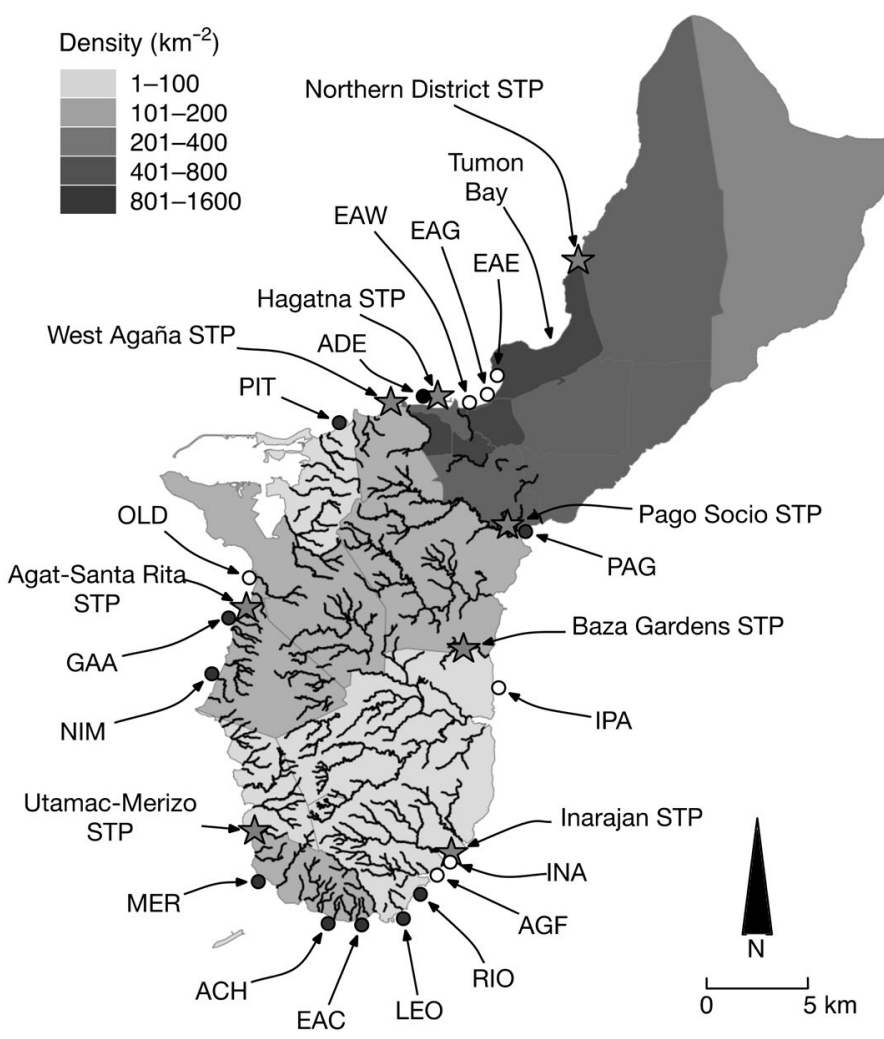

Fig. 1. Human population density on Guam (based on 2010 census) and locations of seagrass study sites (see Table 1 for full site names). : sites that were monitored throughout the course of the study; O: sites that were sampled only in 2011. $\star$ : sewage treatment plants (STP). Note that the northern half of the island, with its carbonate geology, is characterized by an absence of rivers, whereas the volcanic, southern half is replete with rivers beds and ease of access from shore (Burdick 2005) and were at depths of less than $1 \mathrm{~m}$ at high tide. All of the sampling and growth measurements for any given year were completed within $7 \mathrm{~d}$.

At each site during each of the 3 sampling years, 10 randomly placed quadrats $(50 \times 50 \mathrm{~cm})$ were used to measure seagrass cover, assessed from the base of the shoots rather than from the seagrass canopy. Linear growth rates were measured in 2011 and 2013 by punching a hole at the base of seagrass blades $(n=3$ to 8 shoots) and then noting the position of the hole relative to the base of the blade to the nearest $\mathrm{mm}$ after $\sim 5 \mathrm{~d}$, measured to the hour. At Quadrats 1, 5, and 10 at each site, 1 shoot was collected for isotope analysis (total of 3 per site). In 2011, 7 additional sites where E. acoroides occurred but only as sparse patches were sampled to better document the spatial variation in isotope values.

\section{Stable isotope analysis}

Stable isotope analyses were performed to evaluate the likely sources of $\mathrm{N}$ being incorporated by the seagrasses ( $\mathrm{n}=3$ shoots per site per sampling year). In 2011, an additional analysis was performed to examine the variation in isotope values along the length of the shoots (see Yamamuro et al. 2004). Specifically, we compared the isotope values between the tip and base of a shoot, using $\sim 5$ to $20 \mathrm{~cm}$ sections each from a given seagrass blade.

Table 1. Overview of study sites, starting with East Agaña East, the northern-most site, followed by sites around the island of Guam proceeding in a counter-clockwise direction (refer to Fig. 1). Sites marked with an asterisk were used for long-term monitoring; those without an asterisk were sampled only in 2011. Population density data are from the 2010 census (US Census Bureau)

\begin{tabular}{|c|c|c|c|c|c|}
\hline Site name & $\begin{array}{l}\text { Site } \\
\text { code }\end{array}$ & $\begin{array}{l}\text { Latitude } \\
\left({ }^{\circ} \mathrm{N}\right)\end{array}$ & $\begin{array}{l}\text { Longitude } \\
\qquad\left({ }^{\circ} \mathrm{E}\right)\end{array}$ & Municipality & $\begin{array}{l}\text { Pop. density } \\
\text { (ind. } \mathrm{km}^{-2} \text { ) }\end{array}$ \\
\hline East Agaña East & ENE & 13.4927417 & 144.7741944 & Tamuning & 1343 \\
\hline East Agaña Central & EAG & 13.4863222 & 144.7712222 & Tamuning & 1343 \\
\hline East Agaña West & EAW & 13.4799444 & 144.7643694 & Hagatna & 47 \\
\hline Adelup & $\mathrm{ADE}^{*}$ & 13.4777500 & 144.7421750 & Asan & 149 \\
\hline Piti & $\mathrm{PIT}^{*}$ & 13.4692500 & 144.7036667 & Piti & 451 \\
\hline Old Agat & OLD & 13.3979444 & 144.6628889 & Agat & 181 \\
\hline Ga'an & $\mathrm{GAA}^{*}$ & 13.3876583 & 144.6571694 & Agat & 181 \\
\hline Nimitz & NIM $^{*}$ & 13.3656944 & 144.6493333 & Agat & 181 \\
\hline Merizo & $\mathrm{MER}^{*}$ & 13.2655611 & 144.6683167 & Merizo & 75 \\
\hline East Achang & $\mathrm{EAC}^{*}$ & 13.2474722 & 144.7108056 & Merizo & 75 \\
\hline Achang & $\mathrm{ACH}^{*}$ & 13.2493889 & 144.6966667 & Merizo & 75 \\
\hline Leon Guerros & $\mathrm{LEO}^{*}$ & 13.2526944 & 144.7315000 & Inarajan & 113 \\
\hline Rios & $\mathrm{RIO}^{*}$ & 13.2617500 & 144.7374444 & Inarajan & 113 \\
\hline Agfayan Point & AGF & 13.2688611 & 144.7436417 & Inarajan & 113 \\
\hline Inarajan & INA & 13.2716056 & 144.7471139 & Inarajan & 113 \\
\hline Ipan & IPA & 13.3596556 & 144.7714528 & Talofofo & 67 \\
\hline Pago & $\mathrm{PAG}^{*}$ & 13.4239194 & 144.7855139 & Chalan-Pago & 463 \\
\hline
\end{tabular}


For all analyses, the seagrasses were cleared of sediment and epiphytes, dried at $40^{\circ} \mathrm{C}$ for $48 \mathrm{~h}$, ground to a powder with a mortar and pestle, and combusted in a Carlo-Erba NC2500 elemental analyzer coupled, through a Conflo III open-split interface, to a ThermoDelta V Isotope Ratio Mass Spectrometer. Precision, determined by analysis of an in-house acetanilide standard (ACET-5; $10 \%$ N, $71 \%$ C), was $\pm 0.2 \%$. Results are reported as $\delta^{15} \mathrm{~N}$ and $\delta^{13} \mathrm{C}$ values relative to atmospheric $\mathrm{N}_{2}$ and VPDB, respectively.

Water samples $(n=2)$ from the West Agaña sewage treatment plant were collected after treatment but prior to discharge. This plant is one of 7 on Guam, with design capacities ranging from 94 to $45425 \mathrm{~m}^{3}$ $\mathrm{d}^{-1}$ (GWA 2006). The samples were used to establish $\delta^{15} \mathrm{~N}$ in sewage outfalls via the ammonia diffusion method (Sigman et al. 1997). Briefly, 11 of $0.7 \mu \mathrm{m}$ filtered effluent was concentrated via heating in the presence of $\mathrm{MgO}$ to increase the $\mathrm{pH}$ and remove ammonium. Once concentrated to $\sim 250 \mathrm{ml}$, the samples were treated with DeVarda's alloy to convert the remaining nitrate to ammonium, which at high $\mathrm{pH}$ is converted to ammonia gas in the headspace of a sealed container. An acidified glass fiber filter, held between semi-permeable Teflon membranes, was added prior to sealing the container to adsorb the ammonia from the headspace. After incubation at $60^{\circ} \mathrm{C}$ for $5 \mathrm{~d}$, the filters were removed and analyzed to determine $\delta^{15} \mathrm{~N}$.

\section{Precipitation and population data}

Monthly precipitation data, collected at Guam International Airport, were available from the National Climatic Data Center (USA). The data were summarized as monthly means for January to July, which preceded field work in 2009, 2011, and 2013. Human population density data at the municipal level were provided by the Water and Environmental Research Institute of the Western Pacific and the Island Research and Education Initiative based on the 2010 US census data.

\section{Statistical analysis}

Prior to statistical analysis, the data were summarized as follows: replicate (i.e. quadrat) seagrass cover, growth rate, and isotope values were averaged by site and year; daily rainfall data (for 2009, 2011, and 2013) were used to determine monthly totals (in $\mathrm{mm}$ ); and distance to nearest sources of $\mathrm{N}$ inputs (i.e. river mouths and wastewater treatment plants) were estimated using Google Earth ${ }^{\mathrm{TM}}$, taking into consideration general water current patterns (Wolanski et al. 2003).

All of the data were tested for and transformed as needed to meet assumptions of homogeneity of variance (Levene's test) and normality (KolmogorovSmirnov test). Transformations were applied as follows: $\arcsin (\operatorname{sqrt}[\operatorname{cover}]), \log \left(\delta^{15} \mathrm{~N}\right), \log \left(-\left[\delta^{13} \mathrm{C}\right]\right)$, and sqrt(growth rate).

We evaluated whether isotope values were useful predictors of seagrass cover and growth rates using regression analyses. A two-way analysis of variance (ANOVA) was used to test the differences in seagrass cover, linear growth rates, and isotope values using only the data from the 10 sites that were monitored throughout this study. If the ANOVA showed that an interaction term was not significant, the term was removed and the ANOVA rerun. Bonferronicorrected post hoc tests were performed when ANOVA indicated significant differences $(p<0.05)$ among groups. Regression analyses of the 10-site data set were used to evaluate the relationships between isotope values from one survey period to the next. The 2011 data, which included surveys of 17 sites (compared to 10 for the other years), were used to test the effect of distance of sites to terrestrial inputs (river mouths and sewage outfalls) and population density of the municipality in which the sites were located on seagrass $\delta^{15} \mathrm{~N}$ values.

To evaluate whether there is decreasing enrichment in ${ }^{15} \mathrm{~N}$ from along the length of a shoot (Yamamuro et al. 2004), we used a paired $t$-test to compare $\delta^{15} \mathrm{~N}$ values from the base and tip.

\section{RESULTS}

\section{Seagrass cover and growth rates}

The status of seagrasses on Guam varied over the course of our study (Fig. 2, Table 2). We documented significant variation in seagrass cover, ranging from $7 \%$ in Merizo in 2011 to $50 \%$ in Ga'an in 2009. There was no apparent geographic pattern, although the 2 sites with the lowest seagrass cover (Merizo and Achang) were adjacent to one another along the southwest coast of the island. However, when viewed at the island-level (i.e. averaged by survey year) there were no discernible changes in seagrass cover ( $p=0.170$; Table 2), with values ranging from $29 \pm$ $4.6 \%$ (mean $\pm \mathrm{SE}$ ) in 2009 to $31 \pm 3.8 \%$ in 2013 . 

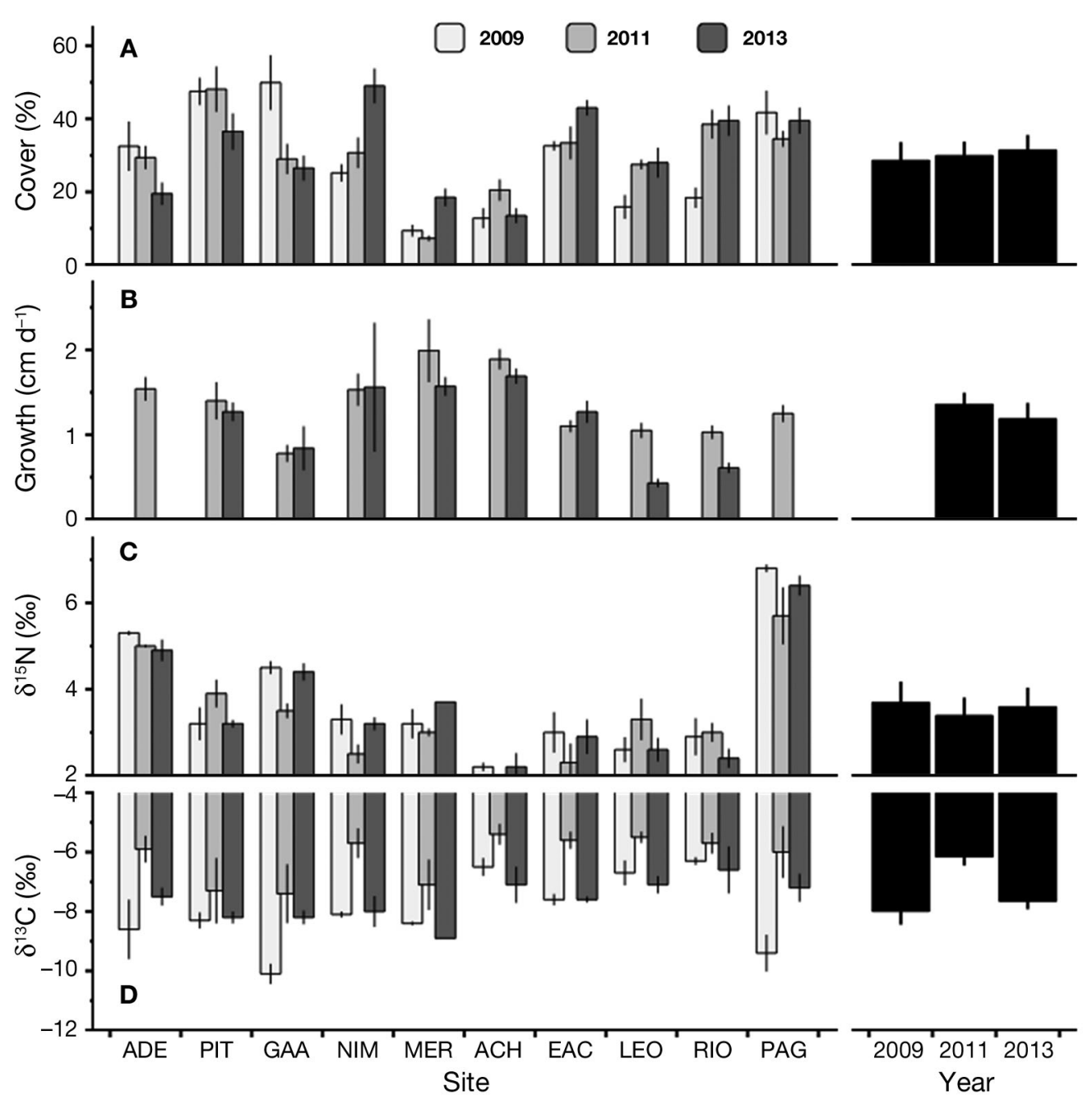

Fig. 2. Enhalus acoroides. Summary of seagrass cover, growth rates, and $\delta^{15} \mathrm{~N}$ and $\delta^{13} \mathrm{C}$ values (mean $\pm \mathrm{SE}$ ) for 10 sites in 2009 , 2011, and 2013. Growth rates were measured in 2011 and 2013 only. Annual means (i.e. sites combined) are presented on the right (black bars). Refer to Fig. 1 and Table 1 for site information

Growth rates were also quite variable. A growth rate of $2 \mathrm{~cm} \mathrm{~d}^{-1}$, the highest measured in this study, was documented at Merizo in 2011. The lowest, at $0.4 \mathrm{~cm} \mathrm{~d}^{-1}$, was measured at Leon Guerros in 2013. Overall, we found that growth rates declined by $\sim 14 \%$ from $2011\left(1.4 \pm 0.12 \mathrm{~cm} \mathrm{~d}^{-1}\right)$ to $2013(1.2 \pm$ $0.17 \mathrm{~cm} \mathrm{~d}^{-1}$ ) (Table 2). The decline was particularly dramatic at Leon Guerros ( $59 \%$ decline) and Rios $(\sim 41 \%)$ between the start and end of the study.

\section{Stable isotope analyses}

We recorded a broad range of $\delta^{15} \mathrm{~N}$ values, from $1.8 \pm 0.13 \%$ at Achang in 2011 to $7.7 \pm 0.25 \%$ at East Agaña East in 2011, a difference of nearly 6\%. For $\delta^{13} \mathrm{C}$, we documented a similar range of values, with the maximum recorded at Achang $(-5.4 \pm 0.35 \%$ in
Table 2. Effect of year, site and their interaction on seagrass cover, shoot growth rates, and stable isotope values, based on ANOVAs

\begin{tabular}{|lccrr|}
\hline $\begin{array}{l}\text { Parameter } \\
\text { Source }\end{array}$ & df & MS & $F$ & $p$ \\
\hline $\begin{array}{l}\text { Seagrass cover } \\
\text { Year }\end{array}$ & 2,18 & 0.038 & 1.78 & 0.170 \\
$\quad$ Site & 9,270 & 0.450 & 20.95 & $<0.001$ \\
Year $\times$ Site & 18,270 & 0.098 & 4.55 & $<0.001$ \\
Growth rate & & & & \\
Year & 1,93 & 0.229 & 6.38 & 0.013 \\
Site & 9,93 & 0.379 & 10.55 & $<0.001$ \\
$\boldsymbol{\delta}^{\mathbf{1 5}} \mathbf{N}$ & & & & \\
Year & 2,71 & 0.005 & 0.92 & 0.404 \\
Site & 9,71 & 0.177 & 34.06 & $<0.001$ \\
$\boldsymbol{\delta}^{\mathbf{1 3}} \mathbf{C}$ & & & & \\
Year & 2,71 & 0.089 & 28.55 & $<0.001$ \\
Site & 9,71 & 0.019 & 6.17 & $<0.001$ \\
\hline
\end{tabular}


2009) and the minimum at East Agaña East (-10.0 \pm $0.19 \%$ in 2011). While there was significant variation among sites for both isotopes (Fig. 2), only $\delta^{13} \mathrm{C}$ varied over time (Table 2). Specifically, we found significant enrichment in ${ }^{13} \mathrm{C}$ between 2009 and 2011 (Bonferroni, $\mathrm{p}<0.001$ ), which then declined in 2013 to 2009 levels ( $p>0.688$; Fig. 2).

At a given site, seagrass $\delta^{15} \mathrm{~N}$ values were dependent on several factors: distance to nearest source of $\mathrm{N}$, human population density in the adjacent municipality, seagrass isotope values from the previous year, and location of the tissue within a seagrass shoot. $\delta^{15} \mathrm{~N}$ values declined as logarithmic function of the distance from input sources, i.e. rivers and wastewater treatment plants, which explained nearly $70 \%$ of the variation in $\delta^{15} \mathrm{~N}$ (Fig. 3). We note that effluents from the West Agaña sewage treatment plant had a $\delta^{15} \mathrm{~N}$ value of $35 \%(\mathrm{n}=2)$. Although not as strong, there was a positive relationship between distance from a point source and $\delta^{13} \mathrm{C}$ values as well $\left(\mathrm{R}^{2}=\right.$ $0.414, p=0.005$; data not shown). Population density of the municipality adjacent to the seagrass site was also strongly related to $\delta^{15} \mathrm{~N}$ values (Fig. 4). However, neither seagrass cover $\left(R^{2}\right.$ ranged from 0.001 to $0.341 ; \mathrm{p}>0.076)$ nor growth rates $\left(\mathrm{R}^{2}=0.003\right.$ to 0.370 ; $\mathrm{p}>0.596$ ) were related to $\delta^{15} \mathrm{~N}$ values (data not shown).

We found that stable isotope values in one survey year were a strong predictor of isotope values in subsequent years (Fig. 5). In particular, $\delta^{15} \mathrm{~N}$ values from 2009 explained more than $96 \%$ of the variation in 2013. A similar pattern, although not as strong, was found for $\delta^{13} \mathrm{C}$ (2011 vs. 2009: $\mathrm{R}^{2}=0.448, \mathrm{p}=0.034$; 2013 vs. 2009 : $R^{2}=0.340, p=0.077 ; 2013$ vs. 2011 : $\mathrm{R}^{2}=0.591, \mathrm{p}=0.009$; data not shown).

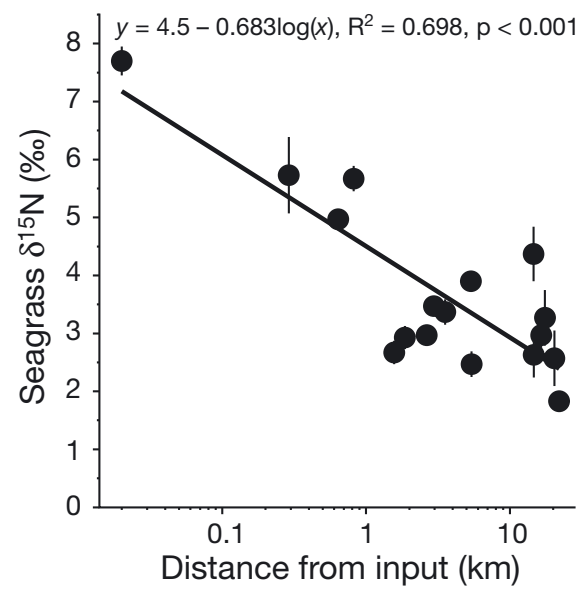

Fig. 3. Relationship between seagrass $\delta^{15} \mathrm{~N}$ values (mean \pm $\mathrm{SE}$ ) and the proximity of the seagrass bed to point sources of $\mathrm{N}$ (rivers and sewage outfalls), based on data from the 2011 survey $(n=17)$

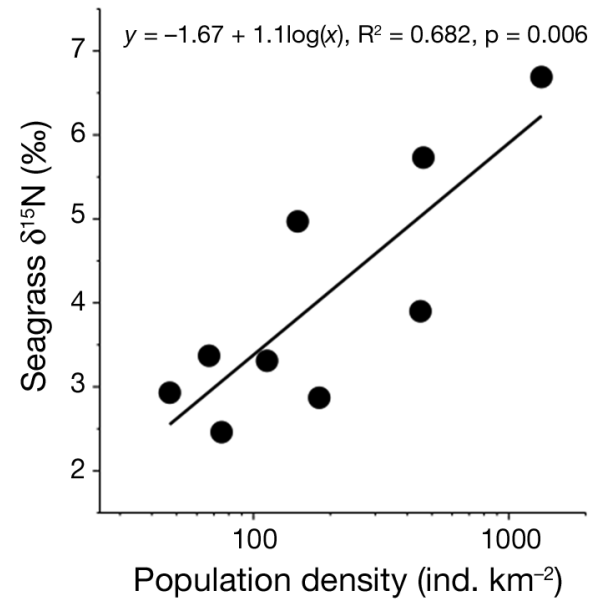

Fig. 4. Relationship between seagrass $\delta^{15} \mathrm{~N}$ values and density of the human population in the municipality adjacent to the seagrass beds, based on data from the 2011 survey ( $\mathrm{n}=$ 9). When there was $>1$ site adjacent to a municipality (see Table 1), an average was used

Consistent with the work of Yamamuro et al. (2004), we found that the base was enriched in ${ }^{15} \mathrm{~N}$ by $0.7 \pm 0.15 \%$ o (mean $\pm \mathrm{SE}$ ) compared to the tip (paired $t$-test, $t_{9}=5.69, \mathrm{p}=0.001$; data not shown). The difference between base and tip appears to be consistent across sites as indicated by a strong correlation between base and tip $\delta^{15} \mathrm{~N}$ values $(\mathrm{r}=0.931, \mathrm{p}<0.001$; data not shown).

\section{Precipitation}

Total monthly precipitation preceding seagrass collection times in July and August differed substantially among years, with the highest level in 2011 (Fig. 6).

\section{DISCUSSION}

Consistent with past records, we found that Enhalus acoroides was the dominant seagrass species, with the other 2 species (Halodule uninervis and Halophila minor) occurring only sporadically and at low densities (K.P. \& K.K. pers. obs.; see also Tsuda et al. 1977, Amesbury et al. 1993). This study is the first quantitative assessment of $E$. acoroides seagrass beds in Guam. Our goals were to build upon the benthic habitat map developed by Burdick (2005) and to examine how the seagrass beds and their surroundings are changing over time. We found that $E$. acoroides cover varied among sites, and growth rates varied among sites and over time. Growth rates were comparable to those in other locations (Table 3). 

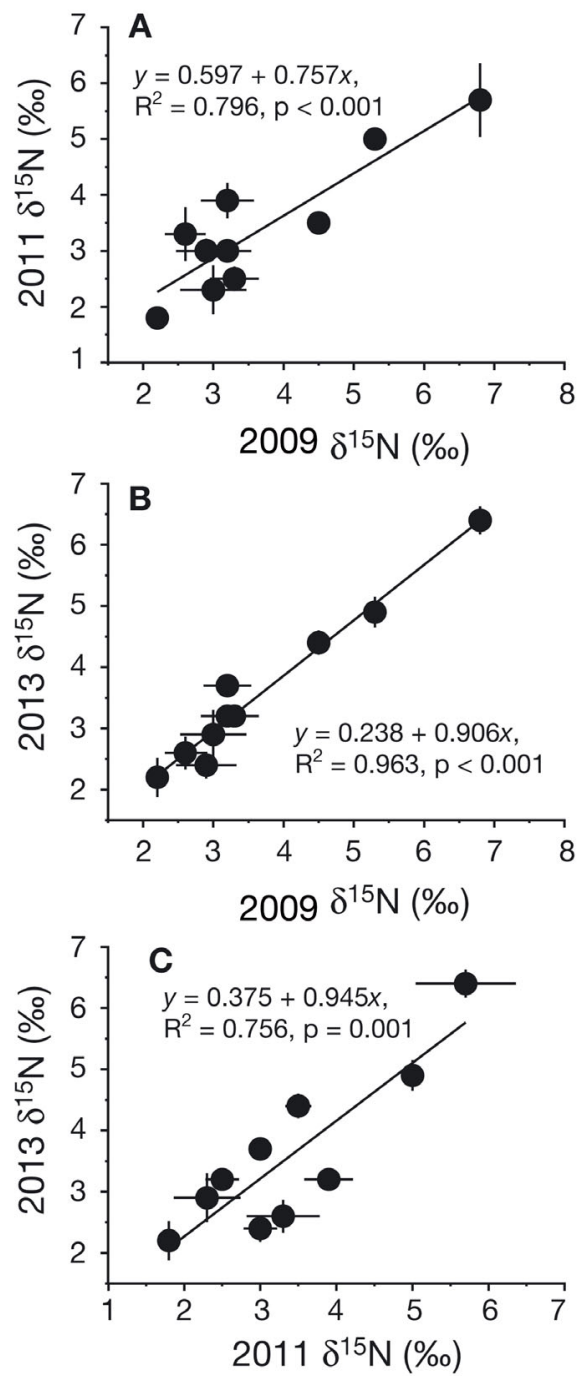

Fig. 5. Relationship between $\delta^{15} \mathrm{~N}$ values of seagrasses (mean $\pm \mathrm{SE}$ ) from year to year. Each point represents one of 10 sites monitored in 2009, 2011, and 2013

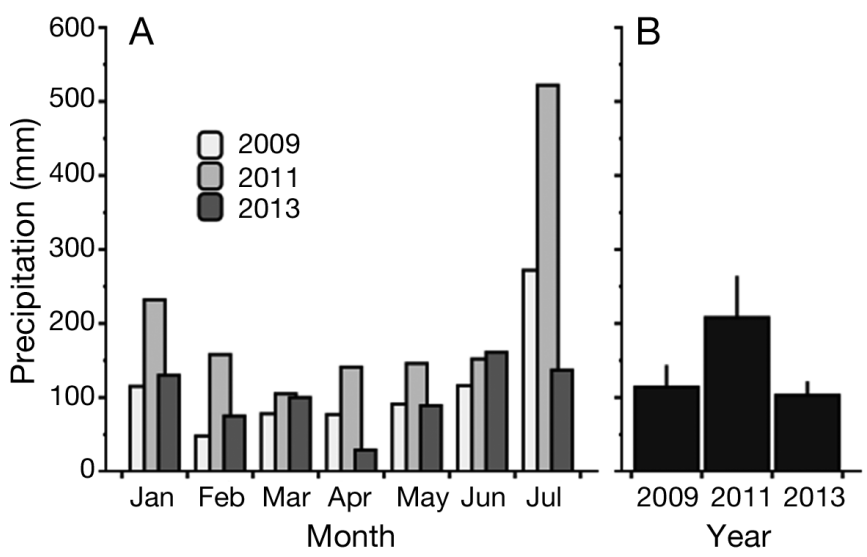

Fig. 6. Precipitation in the months (January to July) preceding sample collections. (A) Monthly totals and (B) annual means $(+\mathrm{SE})$
Table 3. Enhalus acoroides growth rates, including those available from the literature. Values represent overall means in a given study

\begin{tabular}{|lccl}
\hline Location & $\begin{array}{c}\text { Mean } \\
\left(\mathrm{cm} \mathrm{d}^{-1}\right)\end{array}$ & $\begin{array}{c}\text { Max. } \\
\left(\mathrm{cm} \mathrm{d}^{-1}\right)\end{array}$ & \multicolumn{1}{c}{ Source } \\
\hline Philippines & 0.9 & 2.4 & Estacion \& Fortes (1988) \\
$\begin{array}{l}\text { Palau } \\
\text { Papua New }\end{array}$ & 1.0 & 2.0 & Ogden \& Ogden (1982) \\
$\begin{array}{l}\text { Guinea } \\
\text { Australia }\end{array}$ & 1.2 & 2.3 & Johnstone (1979) \\
$\begin{array}{l}\text { Guam } \\
\text { Papua New }\end{array}$ & 1.2 & 2.0 & Kenyon et al. (1997) \\
$\begin{array}{l}\text { Guinea } \\
\text { Thailand }\end{array}$ & 2.1 & 2.5 & Present study \\
Indonesia & 2.4 & - & Erftemeijer et al. (1993) \\
\hline
\end{tabular}

On Guam, human activity has likely been an important driver of coastal ecology for the last several decades. In particular, sewage-derived $\mathrm{N}$ has been a major source of nutrients in Guam's coastal waters (Tsuda \& Grosenbaugh 1977, Denton et al. 2005). Poor wastewater infrastructure-consisting of outdated and inadequate primary and secondary wastewater treatment plants, cesspits, and septic tankshas contributed to the flow of N-rich, sewage-contaminated water into the coastal waters (Matson 1993, GWA 2006). Other sources of $N$ could include upwelling and atmospheric deposition, though neither is likely to be a significant source. The seagrass bed studies were conducted close to shore $(<50 \mathrm{~m})$ and away from the reef front where upwelling could be important. Atmospheric deposition of $\mathrm{N}$ derived from fossil fuel combustion and other human activity is expected to be negligible given the remoteness of Guam and its small population size.

To date, the effects of anthropogenic eutrophication are not well documented. One exception was the report by Denton et al. (2005) on periodic blooms of the filamentous green alga Ulva intestinalis in Tumon Bay, a key beach area for Guam's tourism. The combination of surface and groundwater discharges resulted in elevated $\mathrm{N}$ concentrations in nearshore waters, as high as $8.4 \mathrm{mg} \mathrm{l}^{-1}$, promoting the algal blooms and subsequent fouling of beaches and shorelines (Denton et al. 2005). More recently, Redding et al. (2013) showed that elevated $\mathrm{N}$ inputs from sewage (as measured by $\delta^{15} \mathrm{~N}$ values) were undermining the health of the reefs and were associated with the severity of coral diseases. To date, the only indication of possible accumulating effects on seagrass beds is the decrease in the size of seagrass beds from $9 \%$ in the mid-1970s (Saeland 1978, cited in Eldredge 1983) to the current estimate of $3 \%$ (Burdick 2005). 
Stable isotope analysis of seagrasses in our study provided strong evidence of anthropogenic eutrophication on Guam (Fig. 2). Indeed, the overall $\delta^{15} \mathrm{~N}$ value for $E$. acoroides on Guam $(3.6 \pm 0.2 \%$; mean \pm SE) was well above the mean for tropical seagrasses $(2.7 \pm 0.2 \%)$ and for E. acoroides $(2.3 \pm 0.7 \%)$ in particular (Fig. 7). Given the absence of significant agriculture on Guam (i.e. the absence of significant synthetic fertilizer usage), the combination of highly ${ }^{15} \mathrm{~N}$ enriched effluents (i.e. $35 \%$ ) from sewage treatment plants and sewage-contaminated surface and groundwater discharges (Matson 1993) is likely the dominant source of $\mathrm{N}$ for seagrasses and other benthic organisms.

In contrast to corals in previous studies (e.g. Redding et al. 2013 and references therein), seagrasses in this study appeared to be unaffected by the sewage-derived $\mathrm{N}$ inputs: neither seagrass cover nor growth rates were related to $\delta^{15} \mathrm{~N}$ values. Carruthers et al. (2002) noted that E. acoroides was common in seagrass communities of northeast Australia that received high coastal inputs of sediment and nutrients. Thus, E. acoroides may be adapted to high-N environments. On Guam, in spite of the sewage inputs, the seagrass is likely N-limited and thus benefiting from the elevated $\mathrm{N}$ levels (Udy et al. 1999, Waycott et al. 2005, Lee et al. 2007). This hypothesis is supported by the higher seagrass growth rates documented in 2011 compared to 2013 (Fig. 2B). The difference is likely the result of substantially higher

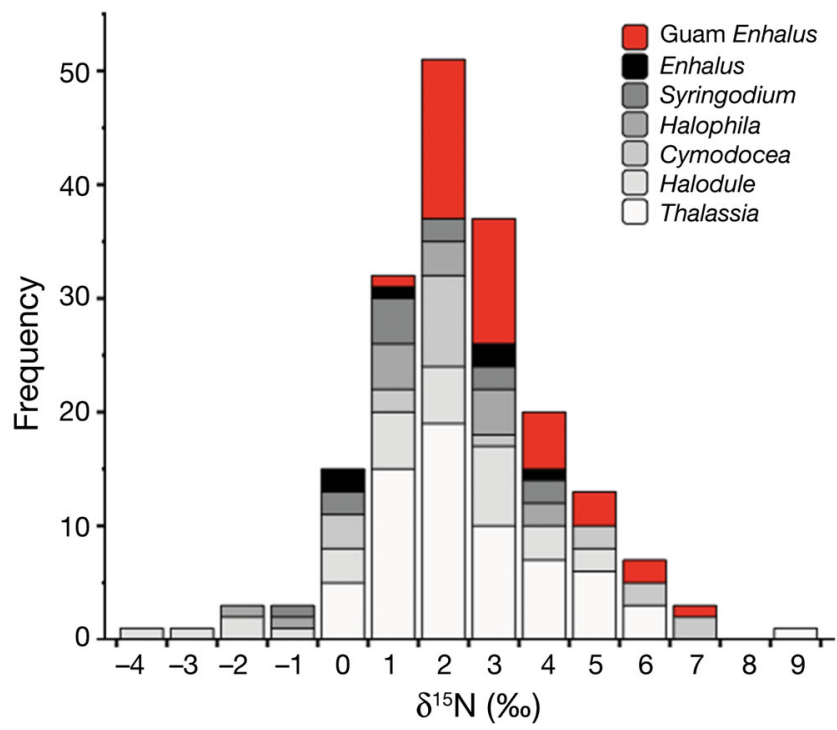

Fig. 7. Distribution of $\delta^{15} \mathrm{~N}$ values for tropical seagrasses based on data from Christiaen et al. $(2014 ; \mathrm{n}=150$; grey bars) and the 2009, 2011, and 2013 surveys in the present study (Guam data; $\mathrm{n}=27$; red bars). Data are presented by genera, and the $x$-axis value represents the lower range of $\delta^{15} \mathrm{~N}$ values for each bin precipitation levels in 2011 and the concomitant increase in the transport of sewage-derived $\mathrm{N}$ into coastal waters (Fig. 2). Denton et al. (2005) noted that dissolved inorganic nitrogen concentrations in Tumon Bay, Guam, can be as high as $1.3 \mathrm{mg} \mathrm{l}^{-1}$ at $50 \mathrm{~m}$ from the shore during the wet season. Such an influx likely shifts seagrasses from $\mathrm{N}$ - to C-limited primary production (O'Leary 1988), resulting in ${ }^{13} \mathrm{C}$ enrichment (Fig. 2D). This hypothesis also predicts that $\delta^{15} \mathrm{~N}$ values should decrease because increasing $\mathrm{N}$ availability should favor ${ }^{15} \mathrm{~N}$ discrimination. Although $\delta^{15} \mathrm{~N}$ values in 2011 were the lowest (Fig. 2C), the difference to 2009 and 2013 was not statistically significant (Table 2).

The $\delta^{15} \mathrm{~N}$ data suggest that sewage-derived $\mathrm{N}$ is most prominent at the northern-most sites and lowest at the south-eastern coast. This pattern appears to reflect the population density, which is especially concentrated across the middle of the island including East Agaña (west coast) and Pago Bay (east coast) (Fig. 1). Not unexpectedly, the highest $\delta^{15} \mathrm{~N}$ value was recorded at East Agaña East (8\%), which is adjacent to Tumon Bay, a well-known tourist destination with more than a million visitors each year (GVB 2012). Seagrasses at Pago Bay, although downstream of a less densely populated municipality, were also highly enriched. This likely reflects the fact that the site is $\sim 300 \mathrm{~m}$ from the mouth of the Lonfit River, along which operates a sewage treatment plant that is composed solely of an aeration tank that disposes of the effluents via percolation fields (Rainey \& Vanlerberghe 2013). In addition, leachate from the recently abandoned public dump in Ordot seeps directly into the Lonfit River.

Isotope analysis of seagrasses provided useful insights into the value of seagrasses as environmental recorders and for understanding coastal $\mathrm{N}$ dynamics on Guam. For instance, we found that the $\delta^{15} \mathrm{~N}$ value of a seagrass can be used to estimate the distance from the nearest source of $\mathrm{N}$ (Fig. 3) and that $\delta^{15} \mathrm{~N}$ values were strongly related to the population density of the adjacent municipality (Fig. 4) (cf. Fernandes et al. 2009, Connolly et al. 2013, Schubert et al. 2013). These results point to inputs of sewagederived $\mathrm{N}$ as a dominant feature of $\mathrm{N}$ dynamics on Guam.

Our finding of a consistent change in $\delta^{15} \mathrm{~N}$ values across all sites between survey years (Fig. 5) suggests that either the conditions at those sites remain unchanged from year to year or that there is a common driver of $\mathrm{N}$ dynamics. Redding et al. (2013) noted significant intra-annual variation in $\delta^{15} \mathrm{~N}$ values in a soft coral and fleshy macroalgae, apparently 
associated with rainfall, supporting the 'common driver' hypothesis. Volcanic substrate dominates the southern half of the island, creating a profusion of river systems that allow rainwater to flow rapidly to the coast, thus increasing the delivery of sewagecontaminated water from urban areas and effluent discharge from sewage treatment plants into coastal waters.

Upon entering the coastal ocean, $\mathrm{N}$ inputs are dispersed by wind-driven alongshore coastal currents as described by Wolanski et al. (2003). Knowledge of local current patterns is critical because proximity of a seagrass bed to a point source may not be relevant if inputs are transported away by the currents. Indeed, such knowledge is essential for realizing the utility of isotope analyses in ecological studies. Another important piece of local knowledge is the range of $\mathrm{N}$ sources that an organism is integrating. In this regard, Guam is ideal because there is a limited number of $\mathrm{N}$ sources, with sewage-derived $\mathrm{N}$ being dominant on shallow reef flats. In other locations, where there are multiple significant sources, using $\delta^{15} \mathrm{~N}$ values as a correlate for ecosystem processes or drivers such as urbanization (Christiaen et al. 2014) is likely to be problematic.

We found no evidence of a negative impact of sewage-derived $\mathrm{N}$ inputs on seagrasses, but that has not been the case for corals (Myers \& Raymundo 2009, Redding et al. 2013). Thus, we conclude that seagrasses are less sensitive to $\mathrm{N}$ pollution than corals, and we therefore suggest that it is important to consider a range of species when evaluating the status of an ecosystem, in order to capture the variation in species' sensitivities to a given environmental driver (e.g. Houk \& van Woesik 2008).

While the present study did not find evidence of a negative effect of $\mathrm{N}$ inputs on seagrasses, continued increases in $\mathrm{N}$ will likely lead to lower water clarity; this will have a negative impact on seagrasses, which have a high light requirement (Orth et al. 2006, Waycott et al. 2009, van Katwijk et al. 2011). Guam is undergoing substantial development and population growth related to a US military realignment, but the plan so far lacks meaningful upgrades of the existing wastewater infrastructure to meet projected needs (EPA 2010, GAO 2013). Given that climate models predict the intensification of precipitation in the region (Karl et al. 2009), we expect that the impact of anthropogenic eutrophication will magnify accordingly. Data presented here provide a useful reference point for tracking such changes over time and for evaluating any future mitigation efforts (Costanzo et al. 2005).
Acknowledgements. We gratefully acknowledge A. Braciszewski, N. Duprey, and T. Reynolds for their help in the field, and M. Fogel and R. Bowden for their support of the isotope work. Comments from E. Kim and S. Vulpas greatly improved the manuscript. This research was supported by NOAA Coral Reef Conservation Program (to L.J.R. and K.K.) and American University Student Research Awards (to K.P. and M.R.C.).

\section{LITERATURE CITED}

Amesbury SS, Tsuda RT, Randall RH, Kerr AM, Smith B (1993) Biological communities in Tumon Bay, 1977-1991. Univ Guam Mar Lab Tech Rep 99

Barbier EB, Hacker SD, Kennedy C, Koch EW, Stier AC, Silliman BR (2011) The value of estuarine and coastal ecosystem services. Ecol Monogr 81:169-193

Brouns JJWM, Heijs FML (1986) Production and biomass of the seagrass Enhalus acoroides (L.f.) Royle and its epiphytes. Aquat Bot 25:21-45

Burdick D (2005) Guam coastal atlas. Univ Guam Mar Lab Tech Rep 114

Burkholder JM, Tomasko DA, Touchette BW (2007) Seagrasses and eutrophication. J Exp Mar Biol Ecol 350: $46-72$

Carruthers TJB, Dennison WC, Longstaff BJ, Waycott M, Abal EG, McKenzie LJ, Long WJL (2002) Seagrass habitats of northeast Australia: models of key processes and controls. Bull Mar Sci 71:1153-1169

Christiaen B, Bernard RJ, Mortazavi B, Cebrian J, Ortmann AC (2014) The degree of urbanization across the globe is not reflected in the $\delta^{15} \mathrm{~N}$ of seagrass leaves. Mar Pollut Bull 83:440-445

Connolly RM, Gorman D, Hindell JS, Kildea TN, Schlacher TA (2013) High congruence of isotope sewage signals in multiple marine taxa. Mar Pollut Bull 71:152-158

Costanzo SD, Udy J, Longstaff B, Jones A (2005) Using nitrogen stable isotope ratios $\left(\delta^{15} \mathrm{~N}\right)$ of macroalgae to determine the effectiveness of sewage upgrades: changes in the extent of sewage plumes over four years in Moreton Bay, Australia. Mar Pollut Bull 51:212-217

Denton GRW, Sian-Denton CM, Concepcion LP, Wood HR (2005) Nutrient status of Tumon Bay in relation to intertidal blooms of the filamentous green alga, Enteromorpha clathrata. Water Environ Res Inst West Pac Univ Guam Tech Rep 110 (available at http://www.weriguam. org/docs/reports/110.pdf)

Eldredge LG (1983) Summary of environmental and fishing information on Guam and the Commonwealth of the Northern Mariana Islands: historical background, description of the islands, and review of the climate, oceanography, and submarine topography. NOAA Tech Memo NOAA-TM-NMFS-SWFC-40

EPA (US Environmental Protection Agency) (2010) EPA comments on the Draft Environmental Impact Statement (DEIS) for the Guam and CNMI Military Relocation, November 2009. EPA, Washington, DC

Erftemeijer PLA, Osinga R, Mars AE (1993) Primary production of seagrass beds in South Sulawesi (Indonesia): a comparison of habitats, methods and species. Aquat Bot 46:67-90

Estacion JS, Fortes MD (1988) Growth rates and primary production of Enhalus acoroides (L.f.) Royle from Lag-It, North Bais Bay, the Philippines. Aquat Bot 29:347-356 
Fernandes M, Bryars S, Mount G, Miller D (2009) Seagrasses as a sink for wastewater nitrogen: the case of the Adelaide metropolitan coast. Mar Pollut Bull 58:303-308

Fourqurean JW, Duarte CM, Kennedy H, Marba N and others (2012) Seagrass ecosystems as a globally significant carbon stock. Nat Geosci 5:505-509

GAO (US Government Accountability Office) (2013) Further analysis needed to identify Guam's public infrastructure requirements and costs for DOD's realignment plan. Report GAO-14-82. GAO, Washington, DC (available at www.gao.gov/assets/660/659751.pdf)

Gössling S (ed) (2003) Tourism and development in tropical islands. Edward Elgar Publishing, Cheltenham

Graci S, Dodds R (2010) Sustainable tourism in island destinations. EarthScan, London

GVB (Guam Visitors Bureau) (2012) Annual report. Available at www.guamvisitorsbureau.com/research-andreports/reports/annual-report

GWA (Guam Waterworks Authority) (2006) Water resource master plan. Available at http://guamwaterworks.org/ compliance-and-safety/water-resources-master-plan/

- Hemminga MA, Mateo MA (1996) Stable carbon isotopes in seagrasses: variability in ratios and use in ecological studies. Mar Ecol Prog Ser 140:285-298

Houk P, van Woesik R (2008) Dynamics of shallow-water assemblages in the Saipan Lagoon. Mar Ecol Prog Ser 356:39-50

Johnstone IM (1979) Papua New Guinea seagrasses and aspects of the biology and growth of Enhalus acoroides (L.f.) Royle. Aquat Bot 7:197-208

Karl TR, Melillo JM, Peterson TC (2009) Global climate change impacts in the United States. Cambridge University Press, New York, NY

Kenyon RA, Conacher CA, Poiner IR (1997) Seasonal growth and reproduction of Enhalus acoroides (L.f.) Royle in a shallow bay in the western Gulf of Carpentaria, Australia. Mar Freshw Res 48:335-342

Lee KS, Park SR, Kim YK (2007) Effects of irradiance, temperature, and nutrients on growth dynamics of seagrasses: a review. J Exp Mar Biol Ecol 350:144-175

Lobban CS, Tsuda RT (2003) Revised checklist of benthic marine macroalgae and seagrasses of Guam and Micro nesia. Micronesica 35:54-99

Marsh JA (1977) Terrestrial inputs of nitrogen and phosphorous on fringing reefs of Guam. Proc Int Coral Reef Symp 1:331-336

Matson EA (1993) Nutrient flux through soils and aquifers to the coastal zone of Guam (Mariana Islands). Limnol Oceanogr 38:361-371

Myers RL, Raymundo LJ (2009) Coral disease in Micronesian reefs: a link between disease prevalence and host abundance. Dis Aquat Org 87:97-104

O'Leary MH (1988) Carbon isotopes in photosynthesis. Bioscience 38:328-336

Ogden JC, Ogden NB (1982) A preliminary study of two representative seagrass communities in Palau, Western Caroline Islands (Micronesia). Aquat Bot 12:229-244

Orth RJ, Carruthers TJB, Dennison WC, Duarte CM and others (2006) A global crisis for seagrass ecosystems. Bioscience 56:987-996

Rainey T, Vanlerberghe D (2013) Waste water collection and treatment inspection for the Guam Waterworks Author- ity. US EPA, San Francisco, CA. Available at http:// dx.doi.org/10.1515/bot.2011.018

Rattanachot E, Prathep A (2011) Temporal variation in growth and reproduction of Enhalus acoroides (L.f.) Royle in a monospecific meadow in Haad Chao Mai National Park, Trang Province, Thailand. Bot Mar 54:201-207

> Redding JE, Myers-Miller RL, Baker DM, Fogel M, Raymundo LJ, Kim K (2013) Link between sewage-derived nitrogen pollution and coral disease severity in Guam. Mar Pollut Bull 73:57-63

Saeland SS (1978) Estimating cover of marine benthic communities: problems and perspectives. Department of Botany, University of Hawaii, Honolulu, HI

Schubert PR, Karez R, Reusch TBH, Dierking J (2013) Isotopic signatures of eelgrass (Zostera marina L.) as bioindicator of anthropogenic nutrient input in the western Baltic Sea. Mar Pollut Bull 72:64-70

Sigman DM, Altabet MA, Michener R, McCorkle DC, Fry B, Holmes RM (1997) Natural abundance-level measurement of the nitrogen isotopic composition of oceanic nitrate: an adaptation of the ammonia diffusion method. Mar Chem 57:227-242

Tsuda RT, Grosenbaugh DA (1977) Agat sewage treatment plant: impact of secondary treated effluent on Guam coastal waters. University of Guam, Water Resources Research Center, Mangilao, GU

Tsuda RT, Fosberg FR, Sachet MH (1977) Distribution of seagrasses in Micronesia. Micronesica 13:191-198

Tsuda RT, Holbrook JL, Wood HR, Donaldson TJ, Smith BD (2004) Biological and chemical survey of the lower Pago River, estuary, near-shore reef channel and adjacent inner reef flat, Pago Bay, Guam. Univ Guam Mar Lab Tech Rep 109

Udy JW, Dennison WC, Long WJL, McKenzie LJ (1999) Responses of seagrass to nutrients in the Great Barrier Reef, Australia. Mar Ecol Prog Ser 185:257-271

> Unsworth RKF, Cullen LC (2010) Recognising the necessity for Indo-Pacific seagrass conservation. Conserv Lett 3: 63-73

van Beukering P, Haider W, Longland M, Cesar HSJ and others (2007) Economic value of Guam's coral reefs. Univ Guam Mar Lab Tech R116

> van Katwijk MM, van der Welle MEW, Lucassen ECHET, Vonk JA and others (2011) Early warning indicators for river nutrient and sediment loads in tropical seagrass beds: a benchmark from a near-pristine archipelago in Indonesia. Mar Pollut Bull 62:1512-1520

> Waycott M, Longstaff BJ, Mellors J (2005) Seagrass population dynamics and water quality in the Great Barrier Reef region: a review and future research directions. Mar Pollut Bull 51:343-350

- Waycott M, Duarte CM, Carruthers TJB, Orth RJ and others (2009) Accelerating loss of seagrasses across the globe threatens coastal ecosystems. Proc Natl Acad Sci USA 106:12377-12381

Wolanski E, Richmond RH, Davis G, Deleersnijder E, Leben RR (2003) Eddies around Guam, an island in the Mariana Islands group. Cont Shelf Res 23:991-1003

Yamamuro M, Umezawa Y, Koike I (2004) Internal variations in nutrient concentrations and the $\mathrm{C}$ and $\mathrm{N}$ stable isotope ratios in leaves of the seagrass Enhalus acoroides. Aquat Bot 79:95-102

Submitted: July 23, 2014; Accepted: March 8, 2015

Proofs received from author(s): April 30, 2015
Editorial responsibility: Morten Pedersen,

Roskilde, Denmark 